\title{
KONTRIBUSI PENGASUHAN ORANGTUA TERHADAP KEMANDIRIAN SISWA SERTA IMPLIKASINYA BAGI PROGRAM BIMBINGAN DAN KONSELING
}

\author{
Fadilla Agustine, Deasy Yunika Khairun, Meilla Dwi Nurmala \\ Jurusan Bimbingan Konseling, Universitas Sultan Ageng Tirtayasa Serang \\ meillanurmala@gmail.com
}

\begin{abstract}
Abstrak
Usia remaja merupakan masa transisi menuju kedewasaan. Namun, beberapa siswa SMA belum menunjukkan sikap yang mengarah pada kedewasaan misalnya mencontek dan mudah dipengaruhi oleh teman. Penelitian ini bertujuan untuk mengetahui hubungan dan besaran kontribusi antara pengasuhan orangtua dengan kemandirian siswa. Hasilnya dapat digunakan untuk merancang program bimbingan dan konseling untuk meningkatkan kemandirian siswa. Penelitian ini menggunakan kuantitatif dengan jenis korelasi. Data dikumpulkan dari 96 siswa kelas XI SMAN 7 Kota Serang melalui angket dan dianalisis menggunakan uji korelasi. Hasilnya menunjukkan bahwa terdapat korelasi positif antara pengasuhan orangtua terhadap kemandirian siswa, meskipun tingkat interpretasi hubungannya rendah. Besaran kontribusi pengasuhan orangtua terhadap kemandirian yakni $11 \%$, yang berarti masih ada $89 \%$ faktor lain yang berkontribusi terhadap kemandirian siswa namun tidak tercakup dalam penelitian ini.
\end{abstract}

Kata kunci: Pengasuhan orangtua, kemandirian siswa, siswa SMA

\begin{abstract}
Adolescence is a transition to maturity. However, some high school students have not shown attitudes that lead to maturity such as cheating and easy to be influenced by friends. This study aims to determine the relationship and the contribution between parenting with student independence. The results can be used to design guidance and counseling programs to improve student independence. This research used quantitative correlation type. Data were collected from 96 grade XI students of SMAN 7 Serang City through a questionnaire and analyzed using the correlation test. The results show that there is a positive correlation between parenting and student independence, even though the level of interpretation of the relationship is low. The amount of parental care contribution to independence is $11 \%$, which means there are still $89 \%$ other factors that contribute to student independence which not include in this study.
\end{abstract}

Key words: Parenting, students independence, Senior High School students 


\section{PENDAHULUAN}

Sekolah Menengah Atas (SMA) merupakan jenjang pendidikan akhir dan menuju ke pendidikan tinggi atau universitas. Siswa SMA dikategorikan ke dalam masa remaja yang berada di rentang usia 15 - 17 tahun. Masa remaja merupakan periode transisi perkembangan antara masa kanak-kanak dengan masa dewasa sehingga, mengalami perubahan-perubahan biologis, kognitif dan sosio-emosinya (Santrock, 2007: 20). Oleh karena mengalami perubahan yang pesat, sebagian siswa SMA yang dikategorikan remaja mengalami ketidaktentuaan saat mereka mencari kedudukan dan identitas.

Kehidupan yang dihadapi siswa SMA menurut Hurlock (Ali dan Asrori, 2015: 107) dipenuhi dengan situasi yang tidak menentu terutama psikologisnya yang tengah berada dalam masa topan dan badai dalam mencari jati dirinya. Selama siswa mencari jati dirinya, tidak terlepas dari fenomena yang terjadi akhir-akhir ini yang menunjukkan kurangnya kemandirian siswa terutama yang berkaitan dengan reaksi emosional maupun proses belajar. Maris (Ali dan Asrori, 2015: 107) mengungkapkan akibat dari adanya reaksi emosional yang berlebihan dapat menimbulkan perkelahian antar pelajar, penyalahgunaan obat dan alcohol dan berbagai perilaku yang mengarah pada tindakan kriminal. Selanjutnya dalam proses belajar Lutfi dan Engkoswara (Ali dan Asrori, 2015: 107) mengungkapkan permasalahan belajar yang timbul adalah kebiasaan belajar yang kurang baik ditandai dengan tidak mampu bertahan lama, keinginan belajar ketika akan menjelang ujian, membolos, menyontek serta mencari bocoran soal ujian. Fenomena tersebut menunjukkan kurangnya kemandirian pada siswa.

Barnadib (Fatimah, 2006: 142) mendefinisikan kemandirian merupakan perilaku mampu berinisiatif, mampu membatasi masalah, mempunyai rasa percaya diri dan dapat melakukan sesuatu sendiri tanpa bantuan orang lain. Siswa yang memiliki kemandirian, mereka akan melakukan segala sesuatu tanpa diperintahkan seperti mentaati semua peraturan sekolah, dapat bertanggung jawab terhadap segala tugas-tugasnya dan belajar dengan giat.

Teori kemandirian yang dikembangkan Steinberg (Budiman, 2010: 3) menyatakan independencegenerally refers to individuals' capacity to behave on 
their own. Maksudnya yaitu kemandirian pada umumnya mengacu pada kemampuan siswa untuk berperilaku dengan cara mereka sendiri, tidak tergantung oleh orang lain dan tidak mudah terpengaruh selain itu, siswa SMA yang dikategorikan sebagai remaja dikatakan mandiri apabila memiliki kemampuan untuk tidak tergantung secara emosional terhadap orang lain terutama orangtua, mampu mengambil keputusan, kemampuan menggunakan prinsip tentang benar atau salah serta penting atau tidak penting. Kemandirian yang dimaksud dapat meliputi tiga hal yakni kemandirian emosional, kemandirian perilaku, dan kemandirian nilai.

Berdasarkan hasil pra observasi, ternyata ditemukan permasalahan kemandirian di kelas XI SMAN 7 Kota Serang. Adapun permasalahan kemandirian siswa yakni: (1) mencontek pada siswa lain pada saat ujian atau mengerjakan PR, (2) mudah terpengaruh oleh siswa lain untuk melanggar peraturan sekolah seperti membolos, terlambat, dan menggunakan handphone pada saat jam pelajaran. Kemandirian memilki arti kecenderungan individu untuk menentukan sendiri aktivitas yang dilakukan dan tidak ditentukan oleh orang lain sehingga, menimbulkan kebergantungan kepada orang lain.

Menurut Ali dan Asrori (2015: 118) Kemandirian siswa dapat ditentukan dari beberapa faktor yaitu gen atau keturunan orangtua, pola asuh orangtua, sistem pendidikan di sekolah dan sistem kehidupan di masyarakat. Yang dimaksud pola asuh ialah cara orangtua mengasuh atau mendidik siswa. Orangtua yang terlalu banyak melarang atau dengan menggunakan kata "jangan" tanpa disertai penjelasan yang rasional akan menghambat perkembangan kemandiriannya. Sebaliknya orangtua yang menciptakan suasana aman dalam berinteraksi akan dapat mendorong perkembangan kemandirian siswa. Demikian juga orangtua yang cenderung lebih sering membanding-bandingkan dengan siswa lain akan berpengaruh kurang baik terhadap perkembangan kemandirian.

Pada hakekatnya tugas orangtua adalah memberikan yang terbaik bagi kehidupan material siswa, memenuhi kebutuhan emosi dan psikologis siswa serta memenuhi kebutuhan pendidikannya. Selanjutnya salah satu tugas orangtua adalah pengasuhan atau biasa disebut dengan parenting. Pengasuhan memiliki arti 
yaitu cara, perbuatan dan mengasuh. Dalam kata mengasuh memiliki makna menjaga, merawat, mendidik, membimbing, melatih, memimpin, dan menyelenggarakan (KBBI, 2018). Istilah asuh sering dirangkaikan dengan asah dan asih menjadi asah, asih dan asuh. Mengasah berarti melatih agar memiliki kemampuan meningkatkan kemampuannya, lain halnya dengan mengasihi yang memiliki arti mencintai dan menyayangi. Pengasuhan sebagai tanggungjawab utama bagi orangtua, karena adanya tuntutan sosial mengenai kewajiban orangtua untuk memberikan yang terbaik bagi kebutuhan material siswa, memenuhi kebutuhan emosi dan psikologis siswa serta menyediakan kesempatan untuk menempuh pendidikan yang terbaik (Lestari, 2016: 36). Berdasarkan kedua istilah tersebut dapat disimpulkan bahwa, pengasuhan merupakan cara yang dilakukan untuk menjaga dan meningkatkan kemampuan siswa, dengan penuh kasih sayang.

Kopko (2007: 1) mengidentifikasi dua aspek pengasuhan orangtua yaitu kontrol dan kehangatan. Kontrol orangtua mengacu pada tingkat dimana orangtua mengelola tingkah siswa, mulai dari sangat mengendalikan hingga menetapkan beberapa peraturan dan tuntutan. Aspek yang berikutnya adalah kehangatan orangtua, aspek ini mengacu pada tingkat dimana orangtua menerima dan merespon tingkah laku siswa sebagai lawan dan menolak. Selanjutnya penelitian ini memfokuskan kepada kontribusi pengasuhan orangtua terhadap kemandirian siswa karena, peran orangtua sangat penting bagi perkembangan siswa khususnya kemandirian.

Pengasuhan orangtua menjadi salah satu faktor yang memberikan kontribusi terhadap kemandirian siswa maka, diperlukan pemahaman mengenai pengasuhan orangtua yang baik kepada orangtua siswa melalui layanan bimbingan dan konseling. Bimbingan dan konseling atau BK pada satuan pendidikan diselenggarakan untuk membantu siswa dalam mencapai tugas-tugas perkembangannya serta memfasilitasi perkembangan siswa untuk mencapai kemandirian, dalam wujud kemampuan memahami diri dan lingkungan, menerima diri, mengarahkan diri, mengambil keputusan, serta merealisasikan diri secara bertanggung jawab sehingga tercapainya kebahagiaan dan kesejahteraan hidup (Panduan Operasional Penyelenggaraan Bimbingan dan Konseling Sekolah 
Menengah Atas, 2016: 6). Oleh karena itu peneliti tertarik mengkaji lebih lanjut tentang kontribusi pengasuhan orangtua terhadap kemandirian siswa kelas XI SMAN 7 Kota Serang serta implikasinya bagi program bimbingan dan konseling.

Bimbingan dan konseling merupakan proses interaksi antara konselor dan konseli baik secara langsung maupun tidak langsung untuk membantu konseli, agar dapat mencapai perkembangan yang optimal. Yusuf dan Nurihsan (2014:11) mengemukakan bimbingan pribadi diarahkan untuk mengambil keputusan, bertanggungjawab atas keputusan yang telah dipilih serta, menerima konsekuensi yang akan dihadapi. Bimbingan pribadi mengarahkan siswa untuk memahami, mengambil keputusan serta mampu meralisasikan keputusannya secara bertanggungjawab sehingga, siswa mampu mencapai perkembangan pribadinya secara optimal (Panduan Operasional Penyelenggaraan Bimbingan dan Konseling, 2016: 35). Dapat disimpulkan bahwa dengan adanya program pribadi ini siswa dapat memahami dirinya serta bertanggung jawab atas dirinya sendiri.

Berdasarkan dapat penelitian kontribusi pengasuhan orangtua terhadap kemandirian siswa, diharapkan penelitian ini mampu memberikan manfaat bagi sekolah SMAN 7 Kota Serang khususnya orangtua siswa kelas XI agar mengetahui pengasuhan orangtua mampu meningkatkan kemandirian siswa.

\section{METODE}

Penelitian ini menggunakan metode kuantitatif dengan teknik korelasi. Tempat penelitian di SMAN 7 Kota Serang yang berlokasi di Jalan Raya Petir Kp. Limpar Kelurahan Curug Kota Serang. Populasi penelitian adalah siswa kelas XI SMAN 7 Kota Serang dengan jumlah sampel sama dengan jumlah populasi karena, jumlah populasi kurang dari 100 atau sama dengan 100 maka, jumlah sampel sebanyak 96 siswa. Data yang diperoleh berdasarkan penyebaran instrumen dua variabel yaitu pengasuhan orangtua $(\mathrm{X})$ dengan menggunakan skala likert dan kemandirian siswa (Y) dengan menggunakan skala Guttman. 


\section{HASIL DAN PEMBAHASAN}

\section{Deskripsi Data}

Deskripsi data diperoleh dari penyebaran instrumen pengasuhan orangtua dan kemandirian siswa dengan sampel sebanyak 96 siswa, yang hasilnya menunjukkan skor minimal pada variabel pengasuhan orangtua diperoleh nilai sebesar 25, sedangkan skor maksimal diperoleh nilai sebesar 100, untuk nilai mean hipotetik diperoleh nilai sebesar 62,5 dan nilai standar defiasinya diperoleh sebesar 12,5. Kemudian pada variabel kemandirian diperoleh skor minimal 0, sedangkan skor maksimal diperoleh nilai sebesar 27 untuk nilai mean hipotetik, diperoleh nilai sebesar 13,5 dan nilai standar defiasinya adalah 4,5. Selanjutnya hasil yang diperoleh dari penyebaran instrumen sebagai berikut:

Hasil yang diperoleh pada varibel X pengasuhan orangtua sebagai berikut:

Tabel 1 Klasifikasi Pengasuhan Orangtua

\begin{tabular}{|c|c|c|c|}
\hline \multirow[b]{2}{*}{ Klasifikasi } & \multicolumn{3}{|c|}{ Rentang } \\
\hline & Skor & $\mathbf{F}$ & $\begin{array}{c}\text { \% Rata- } \\
\text { rata }\end{array}$ \\
\hline Rendah & $X<50$ & 11 & $11 \%$ \\
\hline Sedang & $50 \leq X<75$ & 39 & $41 \%$ \\
\hline Tinggi & $X \geq 75$ & 46 & $48 \%$ \\
\hline \multicolumn{2}{|c|}{ Total } & 96 & $100 \%$ \\
\hline
\end{tabular}

Berdasarkan hasil yang diperoleh dari 96 siswa kelas XI SMAN 7 Kota Serang diketahui bahwa presentase sebesar $11 \%$ atau sebanyak 11 siswa mendapatkan pengasuhan orangtua dalam kategori rendah artinya, orangtua memberikan kebebasan siswa dalam berperilaku tetapi tetap dalam pengawasan, kemudian presentase sebesar $41 \%$ atau sebanyak 39 siswa mendapatkan pengasuhan orangtua dalam ketegori sedang artinya orangtua memberikan kebebasan tidak didampingi dengan pengawasan ataupun sebaliknya dan presentase sebesr $48 \%$ atau sebanyak 46 siswa mendapatkan pengasuhan orangtua dalam kategori tinggi artinya, orangtua terlalu memberikan pengawasan tuntutan dan terlalu memberikan kebebasan siswa dalam bertingkah laku. Sehingga dapat dikatakan siswa kelas XI SMAN 7 Kota Serang mendapatkan pengasuhan orangtua yang lebih tinggi. 
Selanjutnya hasil yang diperoleh pada varibel Y yaitu kemandirian siswa sebagai berikut:

Tabel 2 Klasifikasi Kemandirian

\begin{tabular}{|c|c|c|c|}
\hline \multirow{2}{*}{ Klasifikasi } & \multicolumn{3}{|c|}{ Rentang } \\
\hline & Skor & $\mathbf{F}$ & \% Rata-rata \\
\hline Rendah & $X<9$ & 46 & $49 \%$ \\
\hline Sedang & $9 \leq X<18$ & 44 & $45 \%$ \\
\hline Tinggi & $X \geq 18$ & 6 & $6 \%$ \\
\hline & & 96 & $100 \%$ \\
\hline
\end{tabular}

Berdasarkan hasil yang diperoleh dari 96 siswa kelas XI SMAN 7 Kota Serang diketahui bahwa presentase sebesar $49 \%$ atau sebanyak 46 siswa memiliki kemandirian rendah artinya siswa belum mampu memiliki tanggungjawab untuk mengendalikan dirinya sehingga siswa lebih bergantung kepada orang lain, kemudian presentase sebesar $45 \%$ atau sebanyak 44 siswa memiliki kemandirian sedang artinya siswa mulai mampu mengendalikan dirinya agar tidak bergantung dengan orang lain dan presentase sebesar $6 \%$ atau sebanyak 6 siswa memiliki kemandirian tinggi artinya siswa mampu mengendalikan dirinya untuk bergantung pada orang lain dan lebih bertanggungjawab terhadap dirinya sendiri. Sehingga dapat dikatakan kemandirian siswa kelas XI SMAN 7 Kota Serang berada pada kategori rendah.

\section{Pengujian Prasyarat Analisis}

Uji normalitas bertujuan untuk mengidentifikasi data berdistribusi normal dengan melihat nilai 2-tailedsignificance yaitu jika masing-masing variabel memiliki nilai $>0,05$. Uji normalitas data pengasuhan orangtua dan kemandirian siswa dengan nilai Asymp.Sigunstandardized residual 0.200 yang artinya, lebih besar dari 0,05 sehingga, kedua variabel berdistribusi normal.

Uji linearitas untuk melihat hubungan yang linear dari data yang telah dikumpulkan. Apabila taraf signifikansi lebih besar dari 0,05 maka terdapat hubungan yang linear antara variabel satu dengan variabel yang lainnya sebaliknya, jika signifikansi lebih kecil dari 0,05 maka tidak terdapat hubungan yang linear (Yusuf, 2013: 290). Diperoleh nilai sig defiation of linearity sebesar 
0,634 yaitu lebih besar dari nilai signifikansi 0,05 maka, pengasuhan orangtua dengan kemandirian memiliki hubungan yang linear.

\section{Pengujian Hipotesis}

Pengujian hipotesis dalam penelitian ini adalah menggunakan teknik uji regresi sederhana, bertujuan untuk menemukan persamaan regresi antara pengasuhan orangtua dengan kemandirian siswa. Adapun pengambilan keputusan uji korelasi yaitu:

1. Jika nilai sig (2-tailed) $<0,05$ maka $\mathrm{H}_{0}$ ditolak, $\mathrm{H}_{0}$ ditolak mempunyai arti variabel $\mathrm{x}$ memiliki hubungan dengan variabel $\mathrm{y}$.

2. Jika nilai sig (2-tailed) $>0,05$ maka $\mathrm{H}_{0}$ diterima, $\mathrm{H}_{0}$ diterima mempunyai arti variabel $\mathrm{x}$ tidak memiliki hubungan dengan variabel $\mathrm{y}$.

Hasil uji regresi linear sederhana menyatakan tingkat signifikansnya sebesar $0,001<0,05$ yang artinya, model regresi dapat digunakan untuk memprediksi variabel pengasuhan orangtua $(\mathrm{x})$ berpengaruh terhadap kemandirian $(\mathrm{y})$. Sehingga dari data hasil uji regresi linear dapat dikaitkan dengan hipotesis penelitian ini yaitu:

1. Hipotesis alternative $\left(\mathrm{H}_{\mathrm{a}}\right)$ :

Terdapat hubungan antara pengasuhan orangtua dengan kemandirian siswa kelas XI SMAN 7 Kota Serang.

2. Hipotesis nol $\left(\mathrm{H}_{0}\right)$

Tidak terdapat hubungan antara pengasuhan orangtua dengan kemandirian siswa kelas XI SMAN 7 Kota Serang.

Berdasarkan pengujian regresi sederhana diperoleh nilai signifikansi 0,001 < 0,05 memiliki arti $\mathrm{H}_{0}$ ditolak dan $\mathrm{H}_{\mathrm{a}}$ diterima maka, mengandung arti bahwa terdapat hubungan antara pengasuhan orangtua dengan kemandirian siswa.

Selanjutnya untuk mengetahui arah hubungan pengasuhan orangtua terhadap kemandirian siswa diperoleh dari hasil analisis persamaan regresi yang memiliki nilai konstanta sebesar 11,582 sedangkan nilai pengasuhan orangtua sebesar 0,135 sehingga, persamaan regresinya dapat ditulis $\mathrm{Y}=11,582+0,135 \mathrm{X}$. Persamaan regresi tersebut daapat diartikan bahwa nilai konstanta sebesar 11,582 
menunjukan nilai konstanta variabel pengasuhan orangtua. Nilai koefisien regresi $\mathrm{X}$ sebesar 0,135 menyatakan bahwa setiap penambahan $1 \%$ nilai pengasuhan orangtua maka kemandirian bertambah.Koefisiensi regresi tersebut bernilai positif sehingga, dapat dikatakan bahwa arah hubungan pengasuhan orangtua dengan kemandirian adalah positif.

Analisis koefisien nilai korelasi digunakan untuk melihat seberapa besar variabel independen (x) berpengaruh terhadap variabel dependen (y) yang dinyatakan dalam presentase.Nilai $\left(\mathrm{R}^{2}\right)$ yang kecil berarti kemampuan variabel independen dalam menjelaskan variasi variabel dependen sangat terbatas.Nilai mendekati satu berarti variabel independen memberikan hampir semua informasi yang dibutuhkan untuk memprediksi variasi variabel.dapat diketahui bahwa antara pengasuhan orangtua dengan kemandirian siswa diperoleh korelasi (R) yaitu sebesar 0,332, berdasarkan uji koefisien korelasi peneliti mampu memprediksi tingkat hubungan antara pengasuhan orangtua dengan kemandirian. Nilai koefisien determinasi $\left(\mathrm{R}^{2}\right)$ diperoleh 0,110 memiliki arti pengasuhan orangtua memberikan sumbangan (kontribusi) terhadap kemandirian sebesar 0,110 hal ini menunjukkan sebesar $11 \%$ kontribusi pengasuhan orangtua terhadap kemandirian siswa dan setidaknya ada $89 \%$ faktor lain yang tidak diteliti oleh peneliti yang dapat memberikan kontribusi terhadap kemandirian.

\section{Gambaran Umum Pengasuhan Orangtua Siswa Kelas XI SMAN 7 Kota}

\section{Serang}

Pengasuhan orangtua merupakan tanggung jawab yang dilakukan orangtua untuk memberikan pendidikan, membimbing serta menjaga siswa dengan penuh kasih sayang.Melalui pengasuhan orangtua yang diterapkan dalam kehidupan sehari-hari mampu memberikan perkembangan yang baik bagi siswa secara fisik maupun sosio-emosinya.Hasil pengumpulan data yang dilakukan terhadap 96 siswa diperoleh hasil bahwa siswa SMAN 7 Kota Serang mendapatkan pengasuhan orangtua yang berbeda. Jika dikategorikan terdapat $11 \%$ atau 11 siswa yang mendapatkan pengasuhan orangtua rendah kemudian, terdapat $41 \%$ atau sebanyak 39 siswa yang mendapatkan pengasuhan orangtua sedang dan terdapat $48 \%$ atau sebanyak 46 siswa mendapatkan pengasuhan orangtua yang 
tinggi. Hal ini berarti siswa kelas XI SMAN 7 Kota Serang mendapatkan pengasuhan orangtua yang tinggi.Jika dilihat dari aspek pengasuhan orangtua, siswa kelas XI SMAN 7 Kota Serang mendapatkan kontrol orangtua yang tinggi.

Baumrind (Kopko, 20117:1) kontrol orangtua mengacu pada tingkat dimana orangtua mengelola tingkah laku siswa, mulai dari sangat mengendalikan hingga menetapkan beberapa peraturan dan tuntutan. Kontrol orangtua yang terlalu tinggi dapat mempengaruhi tingkat kemandirian siswa karena semakin banyak larangan dan tekanan yang diberikan orangtua kepada siswa dapat menghambat perkembangan kemandirian siswa, sebaliknya jika orangtua menciptakan suasana aman dalam berinteraksi akan mendorong kemandirian siswa (Ali dan Asrori, 2015: 118).

\section{Gambaran Kemandirian Siswa Kelas XI SMAN 7 Kota Serang}

Kemandirian merupakan segala sesuatu yang dilakukan oleh diri siswa tanpa adanya paksaan dari orang lain, tidak mudah terpengaruh oleh orang lain, serta mampu bertanggung jawab atas segala sesuatu yang telah dilakukannya.Hasil pengumpulan data yang dilakukan terhadap 96 siswa diperoleh bahwa siswa kelas XI SMAN 7 Kota Serang memiliki tingkat kemandirian yang berbeda. Jika dikategorikan terdapat $49 \%$ atau sebanyak 46 siswa yang berada ditingkat kemandirian rendah kemudian, terdapat $45 \%$ atau sebanyak 44 siswa yang berada ditingkat kemandirian sedang sedangkan terdapat $6 \%$ atau sebanyak 6 siswa yang berada ditingkat kemandirian tinggi. Hal ini berarti siswa kelas XI SMAN 7 Kota Serang memiliki kemandirian yang rendah.Jika dilihat dari aspek kemandirian, siswa kelas XI SMAN 7 Kota Serang memiliki kemandirian yang rendah pada aspek kemandirian tingkah laku.

Steinberg (Budiman, 2010: 7) kemandirian tingkah laku berpusat pada siswa mampu membuat keputusan dan menerima konsekuensi atas keputusannya dan menjadikan pendapat serta nasehat orang lain sebagai bahan pertimbangan dalam pengambilan keputusannya. Tetapi, siswa kelas XI SMAN 7 Kota Serang belum mampu memiliki kemandirian perilaku tersebut. 


\section{Kontribusi Pengasuhan Orangtua terhadap Kemandirian Siswa Kelas XI SMAN 7 Kota Serang}

Berdasarkan data penelitian mengenai kontribusi pengasuhan orangtua terhadap kemandirian siswa kelas XI SMAN 7 Kota Serang didapatkan hasil bahwa terdapat hubungan yang positif antara pengasuhan orangtua dengan kemandirian. Berdasarkan hasil uji perhitungan korelasi keduanya memiliki $\mathrm{r}=0,332$ dengan nilai signifikan sebesar 0,001 $<0,05$ yang berarti, kedua variabel pengasuhan orangtua dengan kemandirian siswa memiliki hubungan yang positif. Pengasuhan orangtua memiliki kontribusi terhadap kemandirian siswa sebanyak $11 \%$ sedangkan sisanya sebanyak $89 \%$ faktor lainnya yang tidak diteliti oleh peneliti memberikan kontribusi terhadap kemandirian siswa.

\section{Implikasi bagi Program Bimbingan dan Konseling}

Program bimbingan dan konseling merupakan serangkaian kegiatan yang dirancang secara sistematis untuk orangtua siswa kelas XI SMAN 7 Kota Serang. Permasalahan yang dibahas mengenai pentingnya pengasuhan orangtua terhadap kemandirian siswa dengan harapan, kemandirian siswa dapat meningkat melalui pengasuhan yang diberikan oleh orangtua. Adapun gambaran kegiatan program bimbingan dan konseling sebagai berikut:

Tabel 3 Action Plan

\begin{tabular}{|c|c|c|c|}
\hline Tujuan Layanan & Komponen & Strategi & Materi \\
\hline $\begin{array}{l}\text { Orangtua mampu bersikap wajar dalam } \\
\text { pengendalian siswa. }\end{array}$ & \multirow{2}{*}{$\begin{array}{l}\text { Layanan } \\
\text { Perencanaan } \\
\text { Individual }\end{array}$} & \multirow{2}{*}{$\begin{array}{l}\text { Kolabora } \\
\text { si dengan } \\
\text { Orangtua }\end{array}$} & $\begin{array}{l}\text { Pengendalian yang } \\
\text { wajar }\end{array}$ \\
\hline $\begin{array}{l}\text { Orangtua mampu memberikan aturan dan } \\
\text { batasan dengan diskusi. }\end{array}$ & & & $\begin{array}{c}\text { Orangtua } \\
\text { demokrasi }\end{array}$ \\
\hline $\begin{array}{l}\text { Orangtua mampu berikan kebebasan siswa } \\
\text { untuk memilih kegiatan yang ingin dilakukan } \\
\text { siswa. }\end{array}$ & \multirow{6}{*}{$\begin{array}{l}\text { Layanan } \\
\text { perencanaan } \\
\text { individual }\end{array}$} & & $\begin{array}{l}\text { Kebebasan } \\
\text { kegiatan siswa }\end{array}$ \\
\hline $\begin{array}{l}\text { Orangtua mampu menjadi pendengar yang baik } \\
\text { bagi siswa. }\end{array}$ & & \multirow{5}{*}{$\begin{array}{l}\text { Kolabora } \\
\text { si dengan } \\
\text { orangtua }\end{array}$} & $\begin{array}{c}\text { Orangtua } \\
\text { pendengar yang } \\
\text { baik }\end{array}$ \\
\hline $\begin{array}{l}\text { Orangtua mampu menjadi orangtua sebagai } \\
\text { teman bagi siswa. }\end{array}$ & & & Parents of people \\
\hline Orangtua mampu membagi waktu untuk siswa. & & & Manajemen waktu \\
\hline Orangtua mampu memahami emosi siswa. & & & $\begin{array}{c}\text { Peka terhadap } \\
\text { emosi }\end{array}$ \\
\hline $\begin{array}{l}\text { Orangtua mampu memahami pentingnya } \\
\text { pengasuhan orangtua terhadap kemandirian } \\
\text { siswa }\end{array}$ & & & $\begin{array}{c}\text { Kontribusi } \\
\text { pengasuhan } \\
\text { orangtua terhadap } \\
\text { kemandirian siswa }\end{array}$ \\
\hline
\end{tabular}




\section{SIMPULAN}

Berdasarkan hasil penelitian mengenai kontribusi pengasuhan orangtua terhadap kemandirian siswa kelas XI SMAN 7 Kota Serang, diperoleh kesimpulan sebagai berikut:

1. Gambaran umum pengasuhan orangtua siswa kelas XI SMAN 7 Kota Serang termasuk dalam kategori tinggi yaitu sebesar $48 \%$ dengan aspek kontrol orangtua yang tinggi berarti, siswa mendapatkan pengasuhan yang terlalu memberikan peraturan, cenderung memberikan larangan tanpa memberikan alasan yang jelas.

2. Gambaran umum kemandirian siswa kelas XI SMAN 7 Kota Serang termasuk dalam kategori rendah yaitu sebesar 49\% dengan aspek kemandirian tingkah laku yang memiliki nilai terendah berarti, siswa belum mampu membuat keputusan dan menerima konsekuensi atas keputusan yang akan diambil.

3. Rancangan program bimbingan dan konseling merupakan implikasi dari penelitian ini yang nantinya akan dilaksanakan oleh guru bimbingan dan konseling SMAN 7 Kota Serang, dengan memberikan layanan kepada orangtua siswa kelas XI.

\section{DAFTAR PUSTAKA}

Ali, M., \& Asrori, M. (2015). Psikologi Remaja Perkembangan Peserta Didik. Jakarta: Bumi Aksara.

Budiman, N. (2010). Perkembangan Kemandirian pada Remaja. Bandung: FIP UPI.

Fatimah, E. (2006). Psikologi Perkembangan (Perkembangan Peserta Didik). Bandung: Pustaka Setia.

Hartinah, S. (2010). Pengembangan Peserta Didik. Bandung: PT Refika Aditama.

Kementrian Pendidikan Kebudayaan Direktorat Jendral Guru dan Tenaga Kependidikan. (2016). Panduan Operasional Penyelenggaraan Bimbingan dan Konseling Sekolah Menengah Atas (SMA). Jakarta: Kemendikbud Ditjen GTK.

Kamus Besar Bahasa Indonesia. (2018). Pengasuhan.

Kopko, K. (2007). Parenting Styles and Adolescents. Cornell University. 
Lestari, S. (2016). Psikologi Keluarga Penanaman Nilai dan Penanganan Konflik dalam Keluarga. Jakarta: Pranamedia Group.

Sofa, MA. (2015). Hubungan Pola Asuh Orangtua dengan Kenakalan Remaja pada Siswa/Siswi SMAN 1 Kepohbaru Bojonegoro. Malang: UIN Maulana Malik Ibrahim

Utami, TD. (2014). Kemandirian ditinjau dari Urutan Kelahiran dan Jenis Kelamin.Surakarta: Universitas Muhamadiyah.

Yusuf, MA. (2013). Metode Penelitian Kuantitatif, Kualitatif dan Penelitian Gabungan. Padang.

Yusuf, S. LN., \& Juntika, AN. (2014). Landasan Bimbingan dan Konseling. Bandung: PT Remaja Rosdakarya. 